December 2019

\title{
Genealogical Plagiarism and the Library Community
}

Katherine S. Richers

San Jose State University, karichers@gmail.com

Follow this and additional works at: https://scholarworks.sjsu.edu/ischoolsrj

Part of the Archival Science Commons, Cataloging and Metadata Commons, Collection Development and Management Commons, Educational Psychology Commons, Information Literacy Commons, Museum Studies Commons, Scholarly Communication Commons, and the Scholarly Publishing Commons

\section{Acknowledgements}

I want to thank Dr. Christie Koontz for her encouragement in getting this published and to thank Chris Livingston at the Cal State Bakersfield Walter Stiern Library's Historical Research Center for his support.

\section{Recommended Citation}

Richers, K. S. (2019). Genealogical Plagiarism and the Library Community. School of Information Student Research Journal, 9(2). https://doi.org/10.31979/2575-2499.090205 Retrieved from https://scholarworks.sjsu.edu/ischoolsrj/vol9/iss2/5

This article is brought to you by the open access Journals at SJSU ScholarWorks. It has been accepted for inclusion in School of Information Student Research Journal by an authorized administrator of SJSU ScholarWorks. For more information, please contact scholarworks@sjsu.edu. 


\title{
Genealogical Plagiarism and the Library Community
}

\begin{abstract}
Plagiarism is regarded as an academic crime, but can affect hobbies that rely on research and information sharing such as genealogy. The issue is well-known within the genealogy community. However, information professionals who aid genealogists in their research may not know enough about the issue. How can the library field respond constructively to the issue of uncontrolled plagiarism in genealogy? While the genealogy community condemns plagiarism and offers resources to correct it, current library practices concentrate on services and not on plagiarism education in the genealogy context, concentrating more on copyright and legal problems. The library field can help professionals respond to uncontrolled plagiarism in genealogy by studying the issue. Recommendations for further action include more research on the information-seeking behaviors of genealogists, training information professionals to give both copyright and plagiarism attention and an increase in workshops to educate genealogists on citation.
\end{abstract}

\section{Keywords}

genealogy, plagiarism, information seeking, online communities, digital literacy

\section{Acknowledgements}

I want to thank Dr. Christie Koontz for her encouragement in getting this published and to thank Chris Livingston at the Cal State Bakersfield Walter Stiern Library's Historical Research Center for his support.

\section{About Author}

Katherine S. Richers, M.A., is a MLIS student in the San Jose State iSchool program. She lives in Bakersfield, California. Her educational background is in the humanities (English and history). She currently volunteers at the Historical Research Center at California State University, Bakersfield as she completes her degree. 
Genealogy is a popular hobby in the twenty-first century. Television shows such as Who Do You Think You Are and Finding Your Roots connect public personalities with their own private stories. Genealogists can be found as freelancers on Fiverr or on Ancestry.com asking other users for suggestions on how to find a great-aunt who vanished in the 1920s. While the genealogy community proliferates online, the local library remains a valuable source for the hobby. Besides providing access to records and holding workshops that teach amateur genealogists successful strategies for finding the information they need, librarians can also educate genealogists about ethical concerns such as plagiarism of research and photos. This raises the question of how the library field can react constructively to uncontrolled plagiarism in genealogy.

The current standards in the library and the genealogy communities may not be enough to affect the issue of plagiarism of research. A comparison of current standards from the genealogy and library communities on how to handle plagiarism to how genealogists in the online community view the issue of plagiarism is needed to determine gaps in professionals' knowledge. After highlighting the gaps, it is necessary to discuss the importance of intellectual honesty in professional life and what more can be done to educate information professionals on the problem so that they can help their genealogist patrons more effectively.

When one plagiarizes, one "steal[s] and pass[es] off (the ideas or words of another) as one's own : use[s] (another's production) without crediting the source" ("Plagiarize," 2019, para 1). Plagiarism is thought of as the ultimate academic crime, but plagiarism can be a problem in professional life and in researchoriented hobbies like genealogy. The advent of the web is also important in a discussion of plagiarism in genealogy as the web has made information sharing easier. What this means for information professionals is that besides guiding genealogists in the use of databases and other sources for records, information professionals can educate genealogists on ways to credit their sources properly. Uncontrolled plagiarism erodes trust in information sharing and hinders genealogists' goals. Librarians can help restore that trust.

\section{Literature Review}

While genealogy is often a subject in library and information science scholarship, little research exists on plagiarism in genealogy. Relevant sources are more likely to be found in the library community and the genealogical community. Both communities have ethical standards regarding information sharing; these can be found through professional associations and blogs by community members. The American Library Association has its own committee focusing on genealogy. The committee "provides a forum serving the interests of genealogists and of librarians whose work is in, or related to, the field of genealogy...its objective is to train and assist librarians, especially in history departments and public libraries, who provide service to genealogists" (“Genealogy Committee," 2019, para 1). Genealogists and those who serve them in the information profession have a voice in a major library organization. Since the committee is supposed to aid librarians who work with the genealogy community, they should address ethical concerns somewhere in their guidelines. 
The committee's webpage has a section titled "Genealogy Guidelines and Standards." These consist of guidelines for establishing local collections, for developing genealogical services and collections and for establishing criteria for a unit on genealogical research in schools of library and information science. The section on local collections does not have ethical standards beyond access policy. The section on developing beginning genealogical collections has more promising material. As part of necessary services, information professionals focusing on genealogy should help patrons find the information they need and instruct them on how to do so ("Guidelines for developing a core genealogy collection," 2007). They should also refer genealogists to appropriate libraries and other institutions if their institution does not have the research materials they need. Guides should be provided for accessing research materials ("Guidelines for developing a core genealogy collection," 2007). The guidelines cover rules for information sharing and access, but not plagiarism or how to keep patrons from committing it.

The committee's section on establishing a unit on genealogical research in schools of library and information science lists the study of "ethical and legal issues relating to genealogical librarianship" as a course objective ("Guidelines for a unit or course of instruction in genealogical research," 2007, para. 2). Besides being conscious of the ethics of librarianship and genealogical research, "librarians should be aware of any local, state, or Federal laws that apply to genealogical research and publishing, especially relating to the issues of records access, privacy, and copyright ("Guidelines for a unit or course of instruction in genealogical research,” 2007, para. 11). Copyright and privacy are acknowledged here, but not plagiarism. The "Consumer Issues" section mentions that librarians ought to be familiar with commercial genealogical databases in order to answer patron questions ("Guidelines for a unit or course of instruction in genealogical research," 2007). This would be an opportunity to include plagiarism as an explicit ethical concern, but the opportunity is not taken.

The Board for Certification of Genealogists, a nonprofit founded in 1964 for credentialing genealogists ("About BCG," 2017), has a Code of Ethics. Under this code, a genealogist is meant to protect the public, the client, the profession and people who provide DNA samples. In protecting the public, the genealogist is supposed to quote accurately, cite their sources, present their fees and abilities accurately, keep genealogical information confidential unless they have permission to share it and not "publish or publicize" anything they know to be false ("About BCG," 2017). In protecting the client, genealogists are supposed to reveal potential conflicts of interest, take on paid research commissions only after they have clarified their fees and the scope of the project with the client, explain honestly why a project may not be feasible within the time or budget allotted, and not publish their research without the client's consent ("About BCG," 2017). This set of standards alludes to plagiarism through citation and accurate quoting. Like the training guidelines from the American Library Association's committee on genealogy, the opportunity for constructive ways to handle uncontrolled plagiarism in genealogy is not explicitly taken.

The last two sections of the code focus on protecting the profession and protecting those who submit DNA samples. To protect the profession, the 
genealogist should expose genealogical fraud but not ruin another genealogist, should not pass off someone else's work as theirs and should cite others' material properly. In protecting those submitting DNA samples, the genealogist would explain the risks (like ethnicity surprises) and how privacy is not guaranteed. The genealogist would also follow the terms of the person's consent ("About BCG," 2019). These standards more explicitly deal with the common definition of plagiarism without naming it.

The sampling of standards shows that plagiarism does not seem to be as major of an issue as copyright. However, plagiarism in the online genealogy community is well documented. Ancestry.com used to offer a search engine called OneWorldTree that connected users' trees as a database until 2013 (“Ancestry.com OneWorldTree," 2013). A new version, FamilyTrees, currently exists, and trees can be set as public or private. Users who have set their tree to private can be contacted for guest access to their trees. Users could remove their trees from OneWorldTree if they wished ("Ancestry.com OneWorldTree," 2013). While some users found OneWorldTree useful for filling in information, others objected due to the potential for plagiarism of their more detailed research. Marks (2013) hated the idea of sharing personal family photos via OneWorldTree because he treated them as heirlooms. Close family members could access them, but not casual researchers who were not family. He took pride in the work he performed for family tree research. OneWorldTree also fostered sloppy research through the potential for plagiarism. The Ancestry Insider gives examples of recurring problems with the program: "in my opinion, like Ancestral File before it and New FamilySearch's Family Tree after it, OWT suffers from unmergedduplicates, incorrect merges, endless loops and known inaccuracies"

("OneWorldTree Ancestry.com Dendrology 101: OneWorldTree ${ }^{\circledR}, " 2008$ ). When a service doesn't protect its users, they lose trust in it. When users abuse each other's trust in a hobby that relies on information sharing, the hobby becomes less enjoyable.

Users appear to be concerned with both plagiarism and copyright. Russell (2014) and Tanner (2014) explain the legal implications of plagiarizing trees and research while The Ancestry Insider breaks down the passages that an author has said to have copied and compares them to passages in the original sources ("More accusations of plagiarism leveled at Barry Elwell," 2016). Grossberg (2004), as a history journal editor, discusses the impact of plagiarism on professional research. He has seen both sides: "grappling with charges of plagiarism led me to identify with the victims and to share their sense of being wronged" (Grossberg, 2004). Like Marks (2013), hard work in genealogy is a point of professional and personal pride for Grossberg. Author Barry Elwell was accused of stealing from guides put out by FamilySearch and Rootsweb ("More accusations of plagiarism leveled at Barry Elwell," 2016). Eastman (2016) suggests that the internet is to blame. The internet is a tool; the actions of users and companies are promoting plagiarism.

Plagiarism can be a major ethical crime in professional life as well as in a hobby. Bennett (2016) voices her own concerns about plagiarism as a student of the National Institute of Genealogical Studies: "I guess since it is a real fear it makes me think about the issue even more. At times, I feel like I may be in the 
minority on this point, though" (Bennett, 2016, para. 9). She implies that, in her experience, genealogist peers do not seem to be that concerned with plagiarism. This is not reflected by the content of the community materials. One could argue that in the genealogical community, the amateur members care more about plagiarism than the associations, and therefore provide sources for peers like Bennett.

\section{Discussion}

As mentioned earlier, very few scholarly sources appear to exist about plagiarism in genealogy. Plagiarism in genealogy is known in the community, but professional associations have not quite caught up to their level. Copyright ethics and plagiarism are different issues, but copyright ethics seem to have the most scrutiny. Standards in both communities focus more on copyright possibly because of the legal implications as well as the moral and ethical implications, but plagiarism should not be ignored or downplayed. Users are concerned about plagiarism, but users and services such as Ancestry.com commit or foster plagiarism.

\section{Conclusion}

Plagiarism in genealogy deserves more study in the library and information science field. Increased study could help the field react to plagiarism in genealogy with methods responsive to their audience. Aiding amateur genealogists in ethically researching and citing their information acts as outreach. Information professionals looking to attract more genealogists to their institutions can hold workshops on relevant topics. They could adapt their finding aids to use keywords that would retrieve more specific information for genealogists. Performing user research for creating information retrieval systems can determine what users want. Workshop subjects can include search strategies and digital literacy as well as proper citation. These workshops could be appropriate for other demographics such as students, drawing more patrons to the library. Research shows that genealogists form their own search networks. Surveys about how genealogists using the web view plagiarism safeguards by professional services could inform prevention efforts, as well as surveys for family history researchers seeking to determine motivations behind plagiarism in genealogy.

Raising awareness among the library community about plagiarism in genealogy is part of the library community's duty to its users. In the American Library Association's Code of Ethics, librarians are meant to respect intellectual property rights: "we respect intellectual property rights and advocate balance between the interests of information users and rights holders" ("Professional Ethics," 2008). By educating genealogists and related researchers on proper citation methods and what qualifies as plagiarism, we are keeping to the ethics laid out by the American Library Association. Information sharing is valuable; mentoring other genealogists should not cease because of fears of plagiarism. 


\section{References}

“About BCG.” (2017). BCG. Retrieved from https://bcgcertification.org/ethicsstandards/code/

"Ancestry.com OneWorldTree". (2013). Ancestor Search. Retrieved from http://www.searchforancestors.com/archives/oneworldtree.html

Bennett, S.C. (2016, April 5). "Copyright, plagiarism, and fair use: A genealogist's not so simple guide to the truth." [blog post]. Retrieved from http://blog.genealogicalstudies.com/2016/04/copyright-plagiarism-andfair-use-a-genealogists-not-so-simple-guide-to-the-truth/

"Copyright \& genealogy." (2018). Association of Professional Genealogists. Retrieved from https://www.apgen.org/resources/copyright.html

Eastman, D. (2016, April 1). "Plagiarism raises its ugly head again within the genealogy community." [blog post]. Retrieved from https://blog.eogn.com/2016/04/01/plagiarism-raises-its-ugly-head-againwithin-the-genealogy-community/

"Genealogist's code of ethics." (2018.) BCG. Retrieved from https://bcgcertification.org/ethics-standards/code/

"Genealogy committee." (2019). American Library Association. Retrieved from http://www.ala.org/rusa/sections/history/histcomm/genealogy/genealogy

Grossberg, M. (2004). Plagiarism and professional ethics: A journal editor's view. The Journal of American History, 90(4), 1333-1340. doi:10.2307/3660352

"Guidelines for developing a core genealogy collection." (2007). American Library Association. Retrieved from http://www.ala.org/rusa/resources/guidelines/guidelinesdeveloping

"Guidelines for a unit or course of instruction in genealogical research at schools of library and information science." (2007) American Library Association. Retrieved from http://www.ala.org/rusa/resources/guidelines/guidelinesunit

Marks, K.R. (2013, September 9). No, you can’t have my photos and stories One World Tree [blog post]. Retrieved from http://www.theancestorhunt.com/blog/no-you-cant-have-my-photos-andstories-one-world-tree\#.WrPm3PiG-Uk 
"More accusations of plagiarism leveled at Barry Elwell." (2016). The Ancestry Insider. Retrieved from http://www.ancestryinsider.org/2016/03/moreaccusations-of-plagiarism-leveled.html

"OneWorldTree Ancestry.com Dendrology 101: OneWorldTree®." (2008).

The Ancestry Insider. Retrieved from http://www.ancestryinsider.org/2008/09/oneworldtree.html

"Plagiarize" (2019). Merriam Webster.com. Retrieved from https://www.merriam-webster.com/dictionary/plagiarize

"Professional ethics." (2008). American Library Association. Retrieved from http://www.ala.org/tools/ethics

Russell, J.G. (2014, November 4). It's not sharing [blog post]. Retrieved from http://www.legalgenealogist.com/2014/11/04/its-not-sharing/

Tanner, J. (2014, November 25). Can I sue for plagiarism? [blog post]. Retrieved from http://genealogysstar.blogspot.com/2014/11/can-i-sue-forplagiarism.html 